\title{
KUALITAS PRODUK, HARGA TERHADAP LOYALITAS DAN KEPUASAN KONSUMEN SEBAGAI VARIABEL INTERVENING PENGGUNA TOKOPEDIA DI KABUPATEN GRESIK
}

\author{
Muhammad Rosyihuddin \\ Magister Manajemen, Universitas Muhammadiyah Gresik \\ Gresik, Indonesia, Muhammad.Rosyihuddin@gmail.com
}

\begin{abstract}
Purpose - to find out the extent of satisfaction and the level of loyalty of consumers who have shopped at Tokopedia

Design / Methodology / Approach - In this study, there are two factors that become indifferent for researchers to make reference to independent variables, namely product quality and price. The location of research in Gresik Regency, the number of respondents numbered 100 respondents,

Diterima : 03 Desember 2019 Direview : 11 Desember 2019 Direvisi : 17 Desember 2019 Disetujui : 16 Januari 2020 using purposive sampling method with the provisions of respondents who have made repeated purchases at Tokopedia. The results of this study were analyzed by path analysis and must go through instrument testing, classical assumptions, and then proof of the research hypothesis.

Results and Discussion - Based on the results of research that product quality and price have a direct effect on customer satisfaction and customer satisfaction, product quality and price have a direct effect on loyalty to Tokopedia users in Gresik Regency. While product quality and price have an indirect effect on loyalty through consumer satisfaction of Tokopedia users in Gresik Regency. These results prove that product quality has a smaller coefficient on satisfaction and loyalty than the price variable. Consumer satisfaction and loyalty have a significant effect compared to other variables. Testing the path analysis proves that product quality and price affect indirectly on loyalty through satisfaction, but based on the findings the coefficient value of total product quality is smaller than the price variable.

Conclusion - Based on the results of the study prove that all hypotheses can be accepted (product quality, price, product quality directly and indirectly affect customer satisfaction and loyalty).

Research Implications - it is hoped that the results of this study can add insight to businesses in the field of online business, to pay attention to the quality of products, prices, to foster customer loyalty and satisfaction.
\end{abstract}

Keywords - Product Quality, Price, Consumer Satisfaction, Loyalty.

\begin{abstract}
Abstrak
Tujuan - untuk mengetahui sejauh mana tingkat kepuasan dan tingkat loyalitas konsumen yang telah berbelanja di Tokopedia
\end{abstract}

Desain/ Metodologi/ Pendekatan - Dalam penelitian ini ada dua faktor yang menjadi acuhan bagi peneliti untuk di jadikan refrensi variabel bebas yakni kualitas produk dan harga. Lokasi penelitian di Kabupaten Gresik, jumlah responden berjumlah 100 orang responden, mengunakan metode purposive sampling dengan ketentuan responden yang sudah melakukan pembelian berulang di Tokopedia. Hasil dari penelitian ini dianalisis dengan analisis path dan harus melalui uji instrument, asumsi klasik, dan kemudian pembuktian hipotesis penelitian.

Hasil dan Pembahasan - Berdasarkan hasil penelitian bahwa kualitas produk dan harga berpengaruh secara langsung terhadap kepuasan konsumen, kualitas produk dan harga berpengaruh secara langsung terhadap loyalitas pada pengguna Tokopedia di Kabupaten Gresik. Sedangkan kualitas produk dan harga berpengaruh secara tidak langsung terhadap loyalitas melalui kepuasan konsumen pengguna Tokopedia di Kabupaten Gresik. Hasil tersebut membuktikan bahwa kualitas produk memiliki nilai koefisien lebih 
kecil terhadap kepuasan dan loyalitas dibandingkan variabel harga. Kepuasan konsumen dan loyalitas memiliki pengaruh signifikan dibandingakan variabel-variabel lainnya. Pengujian analisis path membuktikan bahwa kualitas produk dan harga berpengaruh secara tidak langsung terhadap loyalitas melalui kepuasan, akan tetapi berdasarkan hasil temuan nilai koefisien pengaruh total kualitas produk lebih kecil dibandingkan variabel harga.

Kesimpulan - Berdasarkan hasil dari penelitian membuktikan bahwa kesemua hipotesis dapat diterima (kualitas produk, harga, kualitas produk berpengaruh secara langsung dan tidak langsung terhadap kepuasan konsumen dan loyalitas).

Implikasi penelitian - Diharapkan hasil penelitian ini dapat menambah wawasan bagi pelaku usaha di bidang bisnis online, untuk memperhatikan kualitas dari produk, harga, untuk menumbuhkan loyalitas dan kepuasan konsumen.

Kata Kunci - Kualitas Produk, Harga, Kepuasan Konsumen, Loyalitas.

\section{PENDAHULUAN}

Indonesia menyambut era industri 4.0 sebagai gerbang perekonomian digital, kehebatan teknologi digital yang berbasis internet cepat akan lebih mendominasi sebagian besar pola kehidupan manusia dalam menjalankan kehidupan sehari-hari. Pihak yang ada didalamnya adalah industri e-commerce. Meskipun kondisi perekonomian dunia masih dalam keadaan kurang stabil, namun industri e-commerce justru semakin menunjukkan keperkasaannya. Salah satu negara yang menunjukkan perkembangan sangat pesat adalah Indonesia. E-commerce di Indonesia meningkat secara signifikan Tahun 2015, pertumbuhannya hingga 49\%. Beberapa faktor yang menjadi penentu keberhasilan E-commerce karena didukung faktor geografis pasar yang begitu luas, masyarakat perlahan-lahan menjadikan internet sebagai penopang aktivitas seharihari mereka. Dari transportasi hingga aktivitas belanja online" (Fenalosa, 2018).

Memanfaatkan e-commerce dengan mendirikan toko online atau bertujuan untuk mengembangkan bisnis merupakan sebuah peluang yang menguntungkan bagi pelaku usaha tentunya didasari dengan strategi pemasaran atau marketing yang baik. Dasar pemasaran yang baik akan berdampak positif, nantinya akan memberi keuntungan bagi pelaku bisnis mikro atau makro di Indonesia. Pemanfaatan teknologi internet sebagai sistem pemasaran digital merupakan sistem pemasaran diera modern yang dapat menjangkau seluruh wilayah atau seluruh dunia dengan menggunakan basis data dengan sistem pemasaran inter-fungsional (Noor, Rajiani, \& Sulaiman, 2014).

Pengkajian serta pendalaman untuk menentukan arah pemasaran merupakan suatu tujuan yang harus diperhatikan untuk mencapai keberhasilan yang mana tujuan akhirnya untuk memenuhi harapan konsumen (Yoon \& Uysal, 2005). Pemasaran atau marketing mempunyai peran penting dalam pengembangan bisnis atau bertujuan untuk membuka peluang usaha, salah satu faktor yang menentukan keberhasilan pemasaran adalah faktor kepuasan yang dirasakan konsumen (Morisada, Miwa, \& 
Dahana, 2019). Konsumen akan dihadapkan pada suatu kondisi dimana konsumen menilai dan mengukapkan suatu perasaan yang mereka rasakan saat itu, dalam hal ini perasaan yang bekaitan dengan perasaan senang atau kecewa dengan melihat hasil yang mereka badingkan dengan harapan secara lansung, seperti halnya kinerja suatu produk yang dapat dirasakan secara langsung dengan hasil pemakaian yang mana dapat memenuhi harapan atau tidak.

Jika kinerja suatu produk tidak dapat memeberikan kesan pada diri konsumen maka produk tersebut tidak dapat memenuhi harapan konsumen sehingga konsumen kecewa pada produk tersebut, dan jika kinerja suatu produk dapat memberikan dampak yang dapat memenuhi harapan konsumen atau kinerja produk tersebut dapat memenuhi harapan konsumen, maka rasa puas pada konsumen akan timbul karena produk yang mereka terima sesuai dengan keinginannya (Kotler dan Keller, 2017). Maka demikian kepuasan merupakan tolak ukur bagi pengusaha dapat memberi gambaran pendapatan penjualan dalam jangka waktu panjang, kepuasan merupakan suatu hal yang sangat vital karena sifatnya yang tak tersirat dan tak dapat diungkapkan secara langsung. Sikap kecewa konsumen dengan apa yang mereka terima jika hal ini tidak sesuai dengan ekspetasi mereka maka akan berdampak buruk pada tingkat penjualan yang akan terus menurun, hal ini dikarenakan sifat konsumen yang tersirat dengan tidak akan membeli produk itu lagi dan rasa ketidak puasanya mungkin akan dikeluhkan pada konsumen lainnya, tentunya akan menjadi ancaman serius bagi pebisnis dan akan berdampak pada kebangkrutan (Morisada et al., 2019; Xhema, Metin, Groumpos, 2018). Sikap pelanggan yang tidak puas atau kecewa akan bercerita pada orang lain tentang kekecewaanya paling sedikit kepada 15 orang lainnya (Lupiyoadi dan Hamdani, 2014).

Kepuasan konsumen merupakan tahapan-tahapan yang mana tahapan ini menfokuskan pada pemenuhan keinginan konsumen serta mengarahkan pada konsep inti dalam penciptaan laba yakni loyalitas konsumen atau kesetiaaan, (Cheng, Gan, Imrie, \& Mansori, 2018) loyalitas merupakan efek lanjutan dari kepuasan konsumen sehingga loyalitas dan kepuasan memiliki hubungan yang sangat erat (Hult, Sharma, Morgeson, \& Zhang, 2018), loyalitas merupakan indikator yang sangat penting dalam menjalankan sebuah berbisnis, loyalitas merupakan penentu kelangsungan suatu bisnis terutama bisnis yang berorientasi dalam pencapaian laba atau target, (Ali, Kim, Li, \& Jeon, 2018).

Loyalitas dapat mendorong seseorang untuk bersikap merekomendasikan pada konsumen lain untuk membeli suatu produk yang sebelumnya sudah dibelinya (Gómez, Martín-Consuegra, Díaz, \& Molina, 2018). Loyalitas merupakan sikap konsumen yang akan secara otomatis tumbuh setelah apa yang mereka dapatkan terpenuhi atau setelah konsumen itu merasa puas (Meesala 
\& Paul, 2018) Loyalitas merupakan sebuah aset penting bagi pebisnis yang dapat meningkatkan volume penjualan atau meningkatkan laba. Tjiptono, (2014) Loyalitas merupakan bentuk kesetiaan konsumen pada suatu merek tertentu, bahkan loyalitas dapat mendorong seseorang untuk melakukan pembelian berulang yang konsisten dalam jenjang waktu tertentu, dampak positif kesetiaan konsumen tersebut tentu memiliki peran yang sangat penting bagi pengusaha untuk meningkatkan pendapatan. Kesetiaan konsumen juga dapat mendorong pengembangan usaha dengan memberikan masukan atau saran kepada pengusaha agar meningkatkan kualitas produknya".

Kualitas produk merupakan salah satu faktor bagaimana kepuasan dan loyalitas konsumen itu dapat tumbuh. (Delima, Ashary, \& Usman, 2019) Pelanggan akan menilai baik jika spesifikasi kualitas pada suatu produk yang mereka dapatkan sesuai dengan apa yang mereka inginkan atau produk tersebut sesuai dengan apa yang mereka harapan. Dalam transaksi penjualan online haruslah toko online menjual produkproduk dengan kualitas yang baik agar konsumen puasa sehingga loyalitas pada konsumen itu tumbuh. Hallencreutz \& Parmler (2019) Jika produk yang didapatkan konsumen tidak sesuai dengan harapan atau keinginan sebelumnya, maka akan memberikan kesan buruk yang dapat mempengaruhi kepuasan konsumen itu sendiri, sehingga konsumen menjadi tidak loyal sehingga berdampak buruk bagi kelangsungan usahanya. Sikap sebaliknya akan diberikan oleh konsumen jika apa yang didapatkan sesuai dengan harapan dan keinginannya maka akan memberikan efek yang sangat baik, konsumen yang telah mendapatkan produk sesuai harapan dan keinginannya (produk berkualitas) maka konsumen akan merasa puas dan sikap loyal pun akan terus belangsung hingga sampai pada lingkungan konsumen itu berada (Alma, 2013). Kotler dan Keller, (2017) Kualitas produk merupakan keseluruhan ciri yang ada disuatu produk dan karakteristik suatu produk yang memiliki kemampuan untuk memuaskan konsumen untuk pemenuhi kebutuhan yang nantinya akan diutarakan secara lansgung atau tidak oleh konsumen. Lupiyoadi dan Hamdani (2014) Konsumen akan merasa puas terhadap apa yang mereka terima telah memenuhi keinginannya, hal ini menunjukkan bahwa produk yang telah mereka gunakan atau dipakai, dan dikonsumsi adalah produk berkualitas. Karena itu faktor kualitas merupakan salah satu yang harus diperhatikan agar kepuasan dan loyalitas konsumen dapat bertahan dan berkembang. Menurut hasil survei Supriyadi (2017) "Aktifitas belanja online naik, kepuasan konsumen turun" Menunjukkan data survei 43\% konsumen belanja online mengatakan bahwa mereka pernah memiliki pengalaman yang kurang baik dalam berbelanja online. Berdasarkan pengakuan mereka pernah menemukan ketidaksesuaian antara produk 
yang mereka terima dengan foto produk yang terpampang di toko online 62,9\%”. Kepuasan konsumen dengan belanja online secara langsung tergantung pada sejumlah faktor. Hasil kajian penelitian telah dilakukan di Negara Serbia, bahwa kualitas suatu produk dan faktor tingkat harga mempengaruhi kepuasan konsumen yang berbelanja disana (Vasic, Kilibarda, \& Kaurin, 2018).

Kualitas produk merupakan suatu unsur yang sangat penting dalam mempertahankan konsumen agar tidak berlain ke toko online lainnya, pembahasan akan toko online tentunya akan mengarahkan pada suatu nilai yang mana nilai tersebut akan dikeluarkan konsumen untuk mendapatkan suatu produk, hal tersebut dapat diartikan bahwa konsumen akan mendapatkan produk jika konsumen mengeluarkan sebuah nilai untuk mendapat produk yang ingin didapatkannya, dalam hal ini berkaitan tentang faktor harga (Delima et al., 2019). Dalam dunia usaha faktor harga merupakan salah satu yang penting dalam meningkatkan volume penjualan bahkan penentuan harga merupakan sebuah kunci untuk dapat memenangkan persaingan didunia bisnis, kecocokan harga dengan produk yang ditawarkan akan menguatkan kepuasan konsumen dengan loyalitas konsumen. Dalam penjualan online sering kali dapat ditemui beberapa toko online menjual produk yang pada umum dijual dipasaran atau produk yang banyak dijual pada toko online lainnya dengan penentuan harga berbeda, maka salah satu startegi penetapan harga merupakan strategi alternatif yang dapat mempengaruhi persepsi konsumen dalam mempertimbangkan dan untuk memutuskan membeli produk tersebut (Faith \& M. Edwin, 2014; Li, Hardesty, \& Craig, 2018). Lupiyoadi dan Hamdani (2014) Jika konsumen mendapati produk yang dijual dipasaran adalah produk serupa serta memiliki kualitas yang sama, konsumen akan lebih membeli produk dengan harga yang relatif murah, karena presepsi konsumen akan produk tersebut lebih tinggi disebanding produk sejenis. Li, Hardesty, \& Craig (2018); Faith \& M. Edwin, (2014) Penentuan harga suatu produk haruslah tepat sesuai dengan harga jualnya atau sedikit lebih ditekan agar tidak lebih tinggi dari harga pesaing sehingga tidak mengurangi kepuasan setelah membeli produk tersebut, jika harga suatu produk terlalu tinggi maka akan mempengaruhi presepsi konsumen untuk mengabaikan produk yang telah mereka lihat, dalam hal ini produk-produk toko online. Jiang, Luk, \& Cardinali, (2018) Dalam pemasaran permintaan konsumen tingkat harga atau pemberlakuan khusus akan harga mempunyai keterkaitan positif atau lebih buruk jika hal itu sampai diabaikan, artinya jika tingkat penetapan harga suatu produk yang dijual harga jualnya mahal maka permintaan produk tersebut akan menurun, dan jika penetapan suatu harga suatu produk yang dijual harganya relatif murah maka permintaan akan produk tersebut akan terus naik (Li, Nagurney, \& Yu, 2018). 
Dalam penjualan online shopping perbedaan masalah harga sering kali dapat ditemui jika dilihat dari variasi produk sejenis ke toko-toko online lainnya, harga merupakan suatu pembanding jika konsumen ingin membeli suatu produk di toko online maka, faktor harga merupakan unsur utama sebelum produk yang mereka inginkan didapatkan. Persepsi seorang konsumen akan harga memiliki hubungan yang erat dengan kepuasan dan loyalitas (Gómez et al., 2018). Semakin murah harga produk atau semakin terjangkau harga suatu produk, maka akan tinggi tingkat kepuasan dan loyalitas pada diri konsumen (Xhema et al., 2018); (Meesala \& Paul, 2018). Jika harga dipaksakan untuk dinaikan maka loyalitas pelanggan haruslah dapat diminimalkan dengan memberikan harga kompensasi guna meningkatkan nilai jual pada produk yang ditingkatkan harganya tersebut (Xhema et al., 2018). Konsumen memiliki persepsi akan nilai yang tercermin, terutama penetapan harga produk yang ditetapkan perusahaan penyedia produk dan dijualnya secara online. Persaingan akan tingkat harga dapat mempengaruhi pembelian produk perusahaan, hal ini dikarenakan harga dapat menentukan konsumen dalam membeli berulang. Dalam serangkaian masalah yang terkait dengan strategi penetapan harga dan proses keputusan pembelian, perusahaan harus fokus pada mengkomunikasikan nilai kepada pelanggan melalui harga, perusahaan juga harus waspada terhadap harga pesaing dan memeriksa seberapa besar hal itu dapat mempengaruhi pembelian produk mereka (Faith \& M. Edwin, 2014).

Dalam obeservasi awal sebelum penelitian ini dilakukan, peneliti melakukan suvey dengan maksud dan tujuan mendalami atau menggali permasalahanpermasalahan yang sedang terjadi dimasyarakat khususnya mendalami faktor kualitas produk dan harga pada para konsumen pengguna Tokopedia. Survey dilakukan dengan cara memberikan butiranbutiran pertanyaan kepada 100 orang responden yang pernah melakukan teransaksi atau berbelanja secara online di Tokopedia, survey dilaksanakan dibeberapa tempat umum salah satunya tempat perbelanjaan di Kabupaten Gresik. Berdasarkan hasil rekapitulasi survey dari 100 orang responden 53\% responden menjawab produk tidak sesuai dengan apa yang ditawarkan atau kualitas produk masih dibawah harapan, 17\% responden menjawab harga sering kali menjadi salah satu pertimbangan konsumen dalam membeli suatu produk online, menurut mereka harga produk tinggi atau harga produk rendah tidak menjamin produk berkualitas baik, $24 \%$ responden mengeluhkan masalah kualitas produk dengan harga yang dikeluarkan konsumen, artinya harga yang dikeluarkan konsumen tidak sebanding dengan kualitas produk atau produk yang mereka dapatkan tidak sesuai dengan harapan mereka. Sisa 6\% responden memilih tidak memberikan jawaban atau tanggapan. 
E-commerce telah merubah kebiasaan hidup masyarakat dalam berbagai aspek kehidupan terutama dalam berbelanja online. Menangkap adanya peluang pasar didunia e-commerce sebagai tren yang saat ini berkembang, Tokopedia sebagai salah satu developer marketplace di Indonesia yang menyediakan tempat berjualan secara online dengan mendirikan toko seller melalui website, dan dapat diakses secara langsung melalui aplikasi android dan IOS Apple, jika dimanfaatkan dengan optimal maka akan memberikan dampak positif bagi pebisnis terutama pengembangan usaha dan sebagai media alternatif meningkatkan pangsa pasar dalam meningkatkan penjualan dan laba.

Berdasarkan permasalahan diatas, dapat ditarik kesimpulan bahwa kualitas produk, dan harga merupakan strategi yang baik guna membangun kepuasan konsumen dan dampaknya terhadap sikap kesetiaan (loyalitas). Penelitian ini sangat penting untuk dilakukan dengan tujuan akhir yaitu membangun persepsi positif konsumen agar memiliki rasa puas yang mana hal ini akan berdampak terhadap kesetiaan (loyalitas) konsumen itu sendiri. Untuk itu peneliti akan menelusuri bagaimana dan seberapa besarkah pengaruh kualitas produk, harga, kepuasan konsumen dan loyalitas, dengan mengunakan dasar penganalisisan path dengan tujuan mengetahui sebuah hubungan antar variabel yang dipakai dalam penelitian ini. Maka bedasarkan hal tersebut peneliti ingin membuat penelitian dengan judul; "Kualitas Produk, Harga Terhadap
Loyalitas Dan Kepuasan Konsumen Sebagai Variabel Intervening Pada Pengguna Tokopedia Di Kabupaten Gresik”.

\section{TINJAUAN PUSTAKA}

1. Hubungan Kualitas Produk dan Kepuasan Konsumen

Kotler dan Keller (2017) "Kualitas produk yaitu upaya perusahaan dalam menciptakan quality pada suatu produk dan hal ini merupakan suatu startegi yang harus dipenuhi oleh perusahaan dalam memenuhi harapan pelanggan dengan menawarkan suatu produk pada pelanggan. Kualitas layanan merupakan suatu upaya untuk memenuhi harapan para pelanggan melalui jasa yang ditawarkan. Akan tetapi kualitas produk dan kualitas pelayanan memiliki output tujuan yang sama yakni memberikan rasa kepuasan pada para pelanggan. Jika produk yang dihasilkan oleh perusahaan berkualitas buruk maka akan menimbulkan ketidakpuasan pelanggan, tidak hanya pelanggan hal ini akan berdampak terhadap calon pembeli atau pelanggan. "Karena pelanggan yang kecewa akan bercerita paling sedikit kepada 15 orang lainnya" (Lupiyoadi dan Hamdani, 2014). Delima, Ashary, \& Usman (2019) Tujuan utama kualitas produk ialah memenuhi harapan dan keinginan konsumen yang berdampak pada kepuasan konsumen itu sendiri, kualitas merupakan faktor penentu keberlanjutan usaha, yakni semakin baik kualitas, kepuasan meningkat.

Keterkaitan variabel penelitian yang akan di lakukan oleh peneliti akan kualitas 
produk terhadap kepuasan konsumen juga di dukung dan diperkuat dengan penelitian terdahulu oleh Lenzun, Massie, dan Adare (2014) bedasarkan hasil penelitian yang mereka lakukan dapat disimpulkan bahwasa kualitas produk memiliki hubungan positif dan signifikan terhadap kepuasan konsumen. Dasar dari hipotesis penelitian ini mengenai kualitas produk terhadap kepuasan konsumen adalah sebagai berikut: $\mathrm{H}_{1}$ : Ada pengaruh langsung kualitas produk terhadap kepuasan konsumen.

Ho : Tidak ada pengaruh langsung kualitas produk terhadap kepuasan konsumen.

2. Hubungan Harga dan Kepuasan Konsumen

Menurut Tjiptono (2014) Sukses tidaknya suatu produk dipasaran tidak hanya ditentukan oleh pelayanan yang baik akan tetapi juga ditentukan oleh faktor lain seperti harga, dalam memasarkan suatu barang atau jasa, setiap perusahaan harus menetapkan harganya secara tepat.

Harga merupakan penentu untuk mengubah presepsi konsumen dalam berbelanja, hal ini merupakan startegi alternatif yang dapat mempengaruhi presepsi konsumen dalam mempertimbangkan yang pada akhirnya memutuskan untuk membeli produk yang diinginkannya (Faith \& M. Edwin, 2014);(Li, Hardesty, \& Craig, 2018). Lupiyoadi dan Hamdani (2014) "Produk yang memiliki kualitas sama tetapi menetapkan harga yang relatif murah akan memberikan nilai yang lebih tinggi kepada pelanggannya." Li, Hardesty, \& Craig (2018);Faith \& M.
Edwin, (2014) harga produk yang terlalu tinggi akan berdampak terhadap ketidak kepuasan pada konsumen, dan harga yang rendah akan berdampak terhadap kepuasan konsumen. Yakni semakin tinggi tingkat harga yang ditawarkan maka semakin rendah kepuasan pada konsumen, sebaliknya jika harga produk ditawarkan semakin rendah maka akan semakin tinggi tingkat kepuasan pada konsumen.

Keterkaitan variabel harga dan kepuasan konsumen dalam penelitian ini juga memiliki dasar dengan diperkuat oleh penelitian terdahulu oleh Lenzun, Massie, dan Adare (2014) hasil dari analisis penelitian terdahulu secara statistic dapat disimpulkan bahwa variabel harga memiliki hubungan positif dan signifikan terhadap kepuasan konsumen. Maka bedasarkan hasil dari penelitian terdahulu tersebut maka hipotesis penelitian harga terhadap kepuasan konsumen pada penelitian ini adalah sebagai berikut:

$\mathrm{H}_{2}$ : Ada pengaruh langsung harga terhadap kepuasan konsumen.

Ho : Tidak ada pengaruh langsung harga terhadap kepuasan konsumen.

3. Hubungan Kepuasan Konsumen dan Loyalitas

Kepuasan berkontribusi pada sejumlah aspek krusial, seperti terciptanya loyalitas pelanggan (Tjiptono, 2014). Kepuasan pelanggan dapat memberi beberapa manfaat, yakni dapat memberikan dasar yang baik bagi pembelian ulang terutama mendorong terciptanya loyalitas pelanggan, dengan itu reputasi perusahaan terdorong dengan baik 
dimata pelanggan, sehingga laba perusahaan akan meningkat. (Tjiptono dan Diana, 2017). Kepuasan konsumen memiliki kaitan erat dengan loyalitas, (Cheng et al., 2018) karena loyalitas merupakan efek lanjutan dari kepuasan (Hult et al., 2018). Jika konsumen puas akan produk yang telah didapatkannya maka loyalitas akan tercipta, artinya loyalitas merupakan sifat lanjutan konsumen setelah yang diinginkannya dapat terpenuhi, dalam hal ini adalah kepuasan konsumen (Morisada et al., 2019);(Delima et al., 2019).

Dasar dari penelitian ini berdasarkan apa yang ingin di teliti akan keterkaitan kepuasan konsumen terhadap loyalitas, juga diperkuat serta memiliki dasar dengan penelitian terdahulu yaitu oleh Meesala \& Paul, (2018) hasil penelitian yang mereka lakukan bedasarkan hasil temuannya menunjukkan bahwa kepuasan konsumen memiliki hubungan positif dan signifikan terhadap loyalitas. Hipotesis penelitian ini menegenai kepuasan konsumen terhadap loyalitas sebagai berikut:

$\mathrm{H}_{3}$ : Ada pengaruh langsung kepuasan konsumen terhadap loyalitas.

Ho : Tidak ada pengaruh langsung kepuasan konsumen terhadap loyalitas.

4. Hubungan Kualitas Produk dan Loyalitas Produk merupakan indikator yang dapat mempengaruhi loyalitas, perusahaan perlu mempertimbangkan produk yang di jual agar dapat diminati konsumen, hal ini akan memberi dampak pada volume penjualan, tinjauan terhadap kualitas suatu produk sangat penting karena terhubung langsung dengan konsumen karena orientasi target perusahaan (Delima, Ashary, \& Usman 2019)

Keterkaitan variabel tentang kualitas suatu produk terhadap loyalitas konsumen juga diperkuat dengan penelitian terdahulu oleh Xhema, Metin, dan Groumpos. (2018) hasil penelitian yang mereka lakukan menunjukkan bahwa ada hubungan positif dan signifikan antara kualitas produk dan loyalitas konsumen. Berdasar keterkaitan antar variabel kualitas produk dan loyalitas, maka hipotesisnya kualitas produk terhadap loyalitas sebagai berikut:

$\mathrm{H}_{4}$ : Ada pengaruh langsung kualitas produk terhadap loyalitas.

Ho : Tidak ada pengaruh langsung kualitas produk terhadap loyalitas.

5. Hubungan Harga dan Loyalitas

Unsur bauran pemasaran salah satunya adalah harga, harga bersifat fleksibel artinya harga dapat berubah ubah menuruta waktu, kondisi dan tempat. Identifikasi soal harga dapat memberi masukan pada perusahaan untuk melakukan evaluasi harga agar memenuhi harapan konsumen. Harga akan berdampak pada kelangsungan jangka panjang perusahaan, laba perusahaan akan meningkat karena peran loyalitas konsumen (Hsu \& Wang, 2011); (Lenzun et al., 2014). Dimensi harga seperti keterjangakauan harga, daya saing harga, Kotler dan Keller (2017) kesesuaian harga adalah faktor yang menentukan loyalitas suatu konsumen, bisa dilihat pada pengertian hukum permintaan.

Keterkaitan harga terhadap loyalitas juga diperkuat dengan penelitian terdahulu 
oleh Xhema, Metin, dan Groumpos. (2018) hasil penelitian menunjukan bahwa kualitas harga dan loyalitas memiliki hubungan positif. Hipotesis penelitian ini harga terhadap loyalitas adalah sebagai berikut:

$\mathrm{H}_{5}$ : Ada pengaruh langsung harga terhadap loyalitas.

Ho : Tidak ada pengaruh langsung harga terhadap loyalitas.

6. Hubungan Kualitas Produk, Kepuasan, dan Loyalitas

Kualitas produk merupakan indikator yang dapat menciptakan kepuasan dan loyalitas pada konsumen, jika kualitas produk diutamakan maka kepuasan akan terbangun sehingga menumbuhkan loyalitas pada konsumen. Jika kualitas produk meningkat maka kepuasan akan meningkat dan loyalitas akan terbangun. Delima, Ashary, \& Usman, (2019) "Kualitas produk adalah variabel dominan yang mempengaruhi kepuasan konsumen serta berdampak pada loyalitas konsumen. Hal tersebut yang harus diproduksi oleh toko online produk yang berkualitas dan masuk sesuai dengan gambar yang dijual".

Berdasarkan hubungan atau keterkaitan antar variabel kualitas produk, loyalitas, dan kepuasan konsumen, hipotesis penelitian ini kualitas produk terhadap loyalitas melalui kepuasan konsumen sebagai berikut:

$\mathrm{H}_{6}$ : Ada pengaruh tidak langsung kualitas produk terhadap loyalitas melalui kepuasan konsumen.
Ho : Tidak ada pengaruh tidak langsung kualitas produk terhadap loyalitas melalui kepuasan konsumen.

7. Hubungan Harga, Kepuasan, \& Loyalitas Harga merupakan suatu nilai yang harus dikeluarkan konsumen untuk mendapatkan suatu produk atau jasa dengan tujuan memenuhi harapan dan keinginan konsumen, harga menjadi pertimbangan konsumen untuk membeli suatu produk. Harga mempunyai ikatan kuat dalam membangun kepuasan dan loyalitas. Jika harga rendah atau sebanding dengan kualitas yang di berikan maka kepuasan dan loyalitas akan meningkat. Delima, Ashary, \& Usman, (2019) "Harga adalah variabel kedua itu mempengaruhi kepuasan konsumen yang berdampak pada konsumen loyalitas. Jika toko online menawarkan harga terjangkau dan masuk sesuai kualitas produk yang diperoleh berkualitas, pasar permintaan harga akan mempengaruhi kepuasan dan dampak konsumen loyalitas konsumen".

Berdasarkan hubungan atau keterkaitan antar variabel harga, loyalitas, dan kepuasan konsumen, maka hipotesis penelitian kualitas produk terhadap loyalitas melalui kepuasan konsumen sebagai berikut:

$\mathrm{H}_{7}$ : Ada pengaruh tidak langsung harga terhadap loyalitas melalui kepuasan konsumen.

Ho : Tidak ada pengaruh tidak langsung harga terhadap loyalitas melalui kepuasan konsumen. 


\section{METODOLOGI PENELITIAN}

Populasi dalam penelitian ini adalah seluruh pengguna Tokopedia di Kabupaten Gresik yang telah membeli produk Tokopedia lebih dari 2 kali. Jumlah sampel dalam penelitian ini adalah 100 responden yang diambil dengan teknik proposive sampling.

Teknik pengambilan data dalam penelitian ini adalah dengan menggunakan angket (kuesioner). Alat analisis yang digunakan adalah analisis path, sebelum penganalisisan tersebut data harus diuji dengan; (1) Uji instrumen, melalui dua pengujian, yakni; (a) Uji validitas (b) Uji reliabilitas. (2) Uji asumsi klasik. (3) Analisis Path dan Uji Hipotesis.Peneliti menggunakan program analisis SPSS 15 for windows.

\section{HASIL DAN PEMBAHASAN}

Data yang di kumpulkan telah melalui pengujian Instrumen dan uji asumsi klasik, berdasarkan pengujian tersebut data telah memenuhi syarat untuk dilakukan pengujian lanjutan.

\section{Persamaan}

Berikut ini adalah hasil dari analisis jalur berdasarkan hasil penelitian:

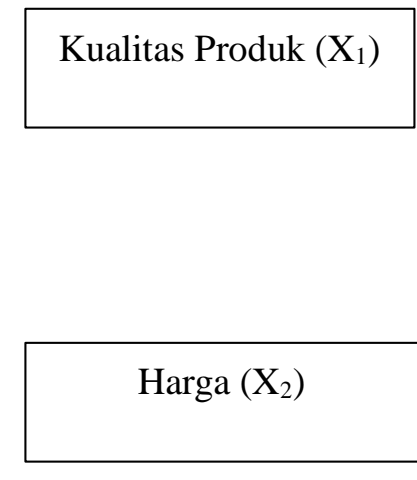

Hasil Persamaan Struktural

$\mathrm{Y}=0,356 \mathrm{X} 1+0,455 \mathrm{X} 2+0,485$

(persamaan struktural 1)

$Z=0,167 X 1+0,192 X 2+0,531 Z+0,377$

(persamaan struktural 2)

\section{Hasil Analisis Jalur Dan Hipotesis}

1. Dari hasil penghitungan pengaruh tidak langsung kualitas produk (X1) terhadap loyalitas (Z) melalui kepuasan konsumen (Y) berdasarkan hasil diatas dengan mengalikan pengaruh $\mathrm{X} 1$ ke $\mathrm{Y}$ dengan $\mathrm{Y}$ ke $Z$ yaitu: 0,356 $\mathrm{x} 0,531=0,189$ serta hasil dari koefisien pengaruh langsung $\mathrm{X} 1$ terhadap $Z=0,167$.
0,167

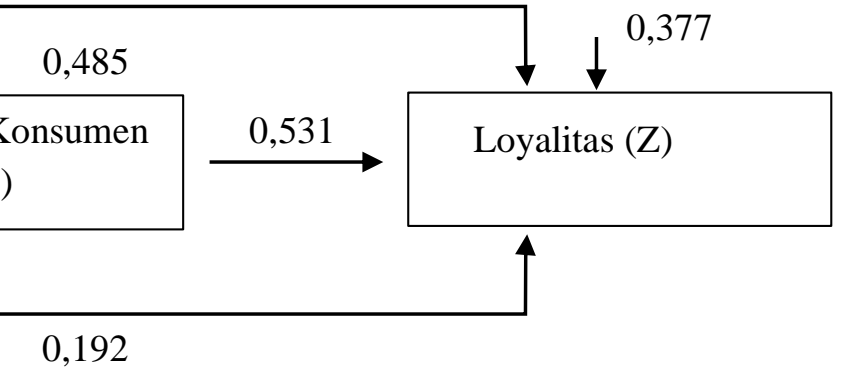

0,192 
lebih besar dari pengaruh langsung sehingga hipotesis 6 "kualitas produk terhadap loyalitas melalui kepuasan konsumen" dalam penelitian ini terbukti. Hal ini berarti $\mathrm{HO}$ ditolak dan H6 diterima.

Hasil penelitian diatas sependapat dengan peneliti terdahulu oleh Delima, Ashary, \& Usman, (2019) "Kualitas produk adalah variabel dominan pertama yang mempengaruhi kepuasan konsumen yang berdampak pada loyalitas konsumen." Kualitas produk haruslah diperhatikan oleh penjual produk online (seller) agar kepuasan konsumen tetap terjaga dan berdampak terhadap loyalitas, kualitas produk merupakan unsur utama untuk membentuk kepuasan konsumen.

2. Berdasarkan hasil dari penghitungan pengaruh tidak langsung variabel harga (X2) terhadap loyalitas (Z) melalui kepuasan konsumen $(\mathrm{Y})$ berdasarkan hasil diatas dengan mengalikan $\mathrm{X} 1$ ke $\mathrm{Y}$ dengan $\mathrm{Y}$ ke $Z$ yaitu: $0,455 \times 0,531=0,241$ serta hasil dari koefisien pengaruh langsung X2 terhadap $Z=0,192$. Besarnya pengaruh tidak langsung harga (X2) terhadap loyalitas (Z) adalah sebesar 0,241 dan pengaruh langsung harga (X2) terhadap loyalitas(Z) adalah sebesar 0,192. Sedangkan pengaruh keseluruhan yang diberikan $\mathrm{X} 2$ terhadap $\mathrm{Z}$ yakni: total pengaruh tidak langsung ditambah total pengaruh langsung $=0,241+0,192=0,443$. Sehingga sesuai hasil perhitungan tersebut dapat disimpulkan bahwa pengaruh tidak langsung harga terhadap loyalitas lebih besar daripada pengaruh langsung harga terhadap loyalitas melalui kepuasan konsumen. Karena pengaruh tidak langsung lebih besar dari pengaruh langsung sehingga hipotesis 7 "harga terhadap loyalitas melalui kepuasan konsumen" dalam penelitian ini terbukti. Hal ini berarti HO ditolak dan H6 diterima.

Hasil penelitian tersebut sesuai penelitian terdahulu, Harga memiliki ikatan dalam membangun kepuasan dan loyalitas, artinya jika harga rendah atau sebanding dengan kualitas yang di berikan maka kepuasan dan loyalitas akan meningkat. Delima, Ashary, \& Usman, (2019) "Harga adalah variabel kedua itu mempengaruhi kepuasan konsumen yang berdampak pada konsumen loyalitas. Jika toko online menawarkan harga terjangkau dan masuk sesuai dengan kualitas produk yang diperoleh berkualitas, permintaan harga akan mempengaruhi kepuasan dan dampak konsumen loyalitas konsumen".

3. Hasil pengolahan data pengaruh langsung variabel kualitas produk terhadap variabel kepuasan konsumen, sebagai berikut:

Tabel 1.

Pengaruh Langsung Kualitas Produk Terhadap Kepuasan Konsumen

\begin{tabular}{|c|c|c|c|c|c|c|}
\hline \multirow{2}{*}{\multicolumn{2}{|c|}{ Model }} & \multicolumn{2}{|c|}{$\begin{array}{c}\text { Unstandardized } \\
\text { Coefficients }\end{array}$} & \multirow{2}{*}{$\begin{array}{c}\text { Standardized } \\
\text { Coefficients }\end{array}$} & \multirow[b]{2}{*}{$t$} & \multirow[b]{2}{*}{ Sig. } \\
\hline & & B & Std. Error & & & \\
\hline \multirow[t]{3}{*}{1} & (Constant) & 3.236 & 1.193 & & 2.713 & .008 \\
\hline & Kualitas Produk & .351 & .084 & .356 & 4.177 & .000 \\
\hline & Harga & .424 & .080 & .455 & 5.327 & .000 \\
\hline
\end{tabular}


Berdasarkan tabel diatas, diketahui besarnya angka $\mathrm{t}$ hitung variabel kualitas produk adalah $4,177>1,98472$ dan nilai signifikansi sebesar $0,000<0,05$. Dengan nilai $t$ hitung lebih besar $t$ tabel dan signifikansi dibawah 0,05 menunjukkan bahwa kualitas produk memiliki pengaruh signifikan terhadap kepuasan konsumen. Hal ini berarti HO ditolak dan $\mathrm{H} 1$ diterima.
Hasil penelitian tersebut sependapat dengan peneliti terdahulu oleh Lenzun, Massie, dan Adare (2014) berdasarkan hasil penelitian mereka dapat disimpulkan bahwa kualitas produk memiliki hubungan positif terhadap kepuasan konsumen.

4. Hasil pengolahan data pengaruh langsung variabel harga terhadap variabel kepuasan konsumen, adalah sebagai berikut:

Tabel 2.

Pengaruh Langsung Harga Terhadap Kepuasan Konsumen

\begin{tabular}{|c|c|c|c|c|c|c|}
\hline \multirow{2}{*}{\multicolumn{2}{|c|}{ Model }} & \multicolumn{2}{|c|}{$\begin{array}{c}\text { Unstandardized } \\
\text { Coefficients }\end{array}$} & \multirow{2}{*}{$\begin{array}{c}\text { Standardized } \\
\text { Coefficients } \\
\text { Beta }\end{array}$} & \multirow[b]{2}{*}{$t$} & \multirow[b]{2}{*}{ Sig. } \\
\hline & & B & Std. Error & & & \\
\hline \multirow[t]{3}{*}{1} & (Constant) & 3.236 & 1.193 & & 2.713 & .008 \\
\hline & Kualitas Produk & .351 & .084 & .356 & 4.177 & .000 \\
\hline & Harga & .424 & .080 & .455 & 5.327 & .000 \\
\hline
\end{tabular}

Berdasarkan tabel diatas, diketahui besarnya angka $\mathrm{t}$ hitung variabel harga adalah 5,327 > 1,98472 dan nilai signifikansi sebesar $0,000<0,05$. Dengan nilai t hitung lebih besar t tabel dan signifikansi dibawah 0,05 tersebut menunjukkan bahwa harga memiliki pengaruh yang signifikan terhadap kepuasan konsumen. Hal ini berarti HO ditolak dan $\mathrm{H} 2$ diterima.

Hasil penelitian tersebut sependapat dengan penelitian sebelumnya oleh Lenzun, mereka mereka membuktikan bahwa harga memiliki hubungan positif terhadap kepuasan konsumen. Hasil penelitian ini sejalan dengan pendapat Lupiyoadi dan Hamdani (2014) "Produk yang mempunyai kualitas sama tetapi menetapkan harga yang relatif murah akan memberikan nilai yang lebih tinggi kepada pelanggannya."

5. Hasil pengolahan data pengaruh langsung variabel kepuasan konsumen terhadap variabel loyalitas, adalah sebagai berikut: Massie, dan Adare (2014) hasil penelitian

Tabel 3

Pengaruh Langsung Kepuasan Konsumen Terhadap Loyalitas

\begin{tabular}{|ll|r|r|r|r|r|}
\hline \multirow{2}{*}{ Model } & \multicolumn{2}{|c|}{$\begin{array}{c}\text { Unstandardized } \\
\text { Coefficients }\end{array}$} & $\begin{array}{c}\text { Standardized } \\
\text { Coefficients }\end{array}$ & & \\
\cline { 3 - 5 } & \multicolumn{1}{|c|}{$\mathrm{B}$} & \multicolumn{1}{|c|}{ Std. Error } & \multicolumn{1}{c|}{ Beta } & \multicolumn{1}{c|}{ Sig. } \\
\hline 1 & (Constant) & -1.963 & 1.385 & & -1.417 & .160 \\
& Kualitas Produk & .207 & .102 & .167 & 2.030 & .045 \\
& Harga & .226 & .101 & .192 & 2.228 & .028 \\
& Kepuas an Konsumen & .671 & .114 & .531 & 5.900 & .000 \\
\hline
\end{tabular}

Berdasarkan tabel diatas, diketahui besarnya angka t hitung variabel keputusan pembelian adalah $5.900>1,98498$ dan nilai signifikansi sebesar $0,000<0,05$. Dengan nilai $\mathrm{t}$ hitung lebih besar $\mathrm{t}$ tabel dan signifikansi dibawah 0,05 menunjukkan 
bahwa kepuasan konsumen memiliki pengaruh yang signifikan terhadap loyalitas. Hal ini berarti HO ditolak dan H3 diterima.

Hasil penelitian diatas sesuai dengan hasil penelitian terdahulu Meesala \& Paul, (2018) berdasarkan hasil penelitian mereka menunjukkan bahwa kepuasan konsumen memiliki hubungan positif dengan loyalitas.

Kepuasan konsumen memiliki keterkaitan yang erat dengan loyalitas, (Cheng et al., 2018) karena loyalitas merupakan efek

lanjutan dari kepuasan (Hult et al., 2018). Jika konsumen puas akan produk yang telah didapatkannya maka loyalitas akan tercipta, artinya loyalitas merupakan sifat lanjutan konsumen setelah yang diinginkannya dapat konsumen terpenuhi, dalam hal ini adalah kepuasan konsumen (Morisada et al., 2019); (Delima et al., 2019).

6. Hasil pengolahan data pengaruh variabel kualitas produk terhadap variabel loyalitas, adalah sebagai berikut:

Tabel 4.

Pengaruh Kualitas produk Terhadap Loyalitas

\begin{tabular}{|c|c|c|c|c|c|c|}
\hline \multirow{2}{*}{\multicolumn{2}{|c|}{ Model }} & \multicolumn{2}{|c|}{$\begin{array}{c}\text { Unstandardized } \\
\text { Coefficients }\end{array}$} & \multirow{2}{*}{$\begin{array}{c}\text { Standardized } \\
\text { Coefficients } \\
\text { Beta }\end{array}$} & \multirow[b]{2}{*}{$t$} & \multirow[b]{2}{*}{ Sig. } \\
\hline & & $\mathrm{B}$ & Std. Error & & & \\
\hline \multirow[t]{4}{*}{1} & (Constant) & -1.963 & 1.385 & & -1.417 & .160 \\
\hline & Kualitas Produk & .207 & .102 & .167 & 2.030 & .045 \\
\hline & Harga & .226 & .101 & .192 & 2.228 & .028 \\
\hline & Kepuasan Konsumen & .671 & .114 & .531 & 5.900 & .000 \\
\hline
\end{tabular}

Berdasarkan tabel 4, dapat diketahui besarnya angka $\mathrm{t}$ hitung variabel kualitas produk adalah 2,030>1,98498 dan nilai signifikansi $0,045<0,05$. Nilai t hitung lebih besar $\mathrm{t}$ tabel dan signifikansi dibawah 0,05 menunjukkan kualitas produk memiliki pengaruh signifikan terhadap loyalitas. Hal ini berarti HO ditolak dan H4 diterima.

Keterkaitan kualitas produk terhadap loyalitas juga sependapat dengan penelitian terdahulu oleh Xhema, Metin, dan Groumpos (2018) berdasarkan hasil penelitian mereka ditemukan bahwa kualitas produk dan loyalitas memiliki hubungan positif, Hal ini membuktikan bahwa kualitas produk yang memenuhi harapan konsumen adalah unsur yang akan berdampak terhadap loyalitas.

7. Hasil pengolahan data pengaruh variabel harga terhadap variabel loyalitas berikut:

Tabel 5

Pengaruh Harga Terhadap Loyalitas

\begin{tabular}{|ll|r|r|r|r|r|}
\hline \multirow{2}{*}{ Model } & \multicolumn{2}{|c|}{$\begin{array}{c}\text { Unstandardized } \\
\text { Coefficients }\end{array}$} & $\begin{array}{c}\text { Standardized } \\
\text { Coefficients }\end{array}$ & & \\
\cline { 2 - 5 } & \multicolumn{1}{|c|}{$\mathrm{B}$} & \multicolumn{1}{|c|}{ Std. Error } & \multicolumn{1}{c|}{ Beta } & \multicolumn{1}{c|}{$\mathrm{t}$} & \multicolumn{1}{c|}{ Sig. } \\
\hline 1 & (Constant) & -1.963 & 1.385 & & -1.417 & .160 \\
& Kualitas Produk & .207 & .102 & .167 & 2.030 & .045 \\
& Harga & .226 & .101 & .192 & 2.228 & .028 \\
& Kepuasan Konsumen & .671 & .114 & .531 & 5.900 & .000 \\
\hline
\end{tabular}

Berdasarkan tabel diatas, dapat harga 2,228 > 1,98498 dan nilai signifikansi diketahui besarnya angka $\mathrm{t}$ hitung variabel sebesar 0,028<0,05. Nilai $\mathrm{t}$ hitung lebih 
besar $\mathrm{t}$ tabel dan signifikansi dibawah 0,05 tersebut menunjukkan harga memiliki pengaruh yang signifikan terhadap loyalitas, hal ini berarti HO ditolak dan H5 diterima.

Keterkaitan harga terhadap loyalitas juga sependapat dengan penelitian terdahulu oleh Xhema, Metin, dan Groumpos (2018), hasil penelitian mereka menunjukan bahwa kualitas harga dan loyalitas memiliki hubungan positif. Kotler dan Keller (2017) kesesuaian harga adalah faktor yang dapat menentukan loyalitas suatu konsumen, bisa dilihat kembali pada pengertian hukum permintaan. Laba perusahaan akan meningkat karena peran loyalitas konsumen (Hsu \& Wang, 2011, Lenzun et al., 2014).

\section{KESIMPULAN}

Berdasarkan hasil pengujian ketujuh hipotesis yang telah dianalisis, maka dapat diambil kesimpulan, sebagai berikut:

1. Hasil pengujian hipotesis penelitian menunjukan bahwa kualitas produk berpengaruh secara langsung terhadap kepuasan konsumen pada pengguna Tokopedia di Kabupaten Gresik.

2. Hasil pengujian hipotesis penelitian menunjukan bahwa harga berpengaruh secara langsung terhadap kepuasan konsumen pada pengguna Tokopedia di Kabupaten Gresik.

3. Hasil dari pengujian hipotesis penelitian menunjukan bahwa kepuasan konsumen berpengaruh secara langsung terhadap loyalitas pada pengguna Tokopedia di Kabupaten Gresik.

4. Hasil dari pengujian hipotesis penelitian menunjukan bahwa kualitas produk berpengaruh secara langsung terhadap loyalitas pada pengguna Tokopedia di Kabupaten Gresik.

5. Hasil dari pengujian hipotesis penelitian menunjukan harga berpengaruh secara langsung terhadap loyalitas pengguna Tokopedia di Kabupaten Gresik.

6. Hasil dari pengujian hipotesis penelitian menunjukan bahwa kualitas produk berpengaruh secara tidak langsung terhadap loyalitas melalui kepuasan konsumen pada pengguna Tokopedia di Kabupaten Gresik.

7. Hasil dari pengujian hipotesis penelitian menunjukan bahwa harga berpengaruh tidak langsung terhadap loyalitas melalui kepuasan konsumen pada pengguna Tokopedia di Kabupaten Gresik.

Berdasarkan kesimpulan yang merupakan implikasi dari hasil penelitian yang dilakukan mengenai pengaruh kualitas produk dan harga terhadap loyalitas melalui kepuasan konsumen sebagai variabel intervening pada pengguna Tokopedia di Kabupaten Gresik, rekomendasi yang dapat diberikan adalah sebagai berikut:

1. Rekomendasi kepada Tokopedia, kualitas produk memiliki pengaruh lebih kecil terhadap kepuasan dan loyalitas dibandingkan dengan variabel harga. Berdasar analisis peneliti merekomendasi agar Tokopedia selaku pihak developer yang mengembangkan aplikasi dan menyediakan tempat berjualan secara 
online untuk menambahkan fitur baru cek kualitas produk (QC) yang yang mana fitur tersebut dapat memberi manfaat pada penjual dan dapat membantu penjual mengkonfirmasi pembeli ketika pembeli melihat etalase produk dan deskripsi produk toko penjual (seller).

2. Rekomendasi kepada reseller atau penjual produk di Tokopedia, agar menjaga dan meningkatkan kualitas produk sebagai acuhan startegi pemasaran guna meningkatkan nilai kepuasaan pada konsumen (pembeli) sehingga dapat memberikan dampak kepuasan dan loyalitas yang mana hal ini akan memberikan manfaat serta dampak positif dalam meningkatkan laba atau penjualan, berdasarkan hasil analisis kualitas produk memiliki pengaruh lebih kecil terhadap loyalitas melalui kepuasan dibandingkan variabel harga, jika kualitas produk tidak ditingkatkan maka seiring berjalannya waktu hal ini akan berakibat kekecewaan pada konsumen keberadaan e-commerce di indonesia kurang diminati dan ditinggalkan oleh konsumen. Jika kualitas produk ditingkatkan maka nilai kepuasanpun akan meningkat, dan jika kualitas produk tidak ditingkatkan maka nilai kepuasan pada konsumen akan menurun.

3. Direkomenadikan pada reseller Tokopedia agar mempertahankan variabel harga, berdasar hasil analisis harga memiliki pengaruh lebih tinggi dan signifikan dibandingkan variabel kualitas produk, penjual harus mempertahankan harga sebagai strategi penetapan harga yang dapat bersaing, hal ini merupakan salah satu strategi untuk memenangkan persaingan terutama dalam bisnis toko online di Tokopedia, harga tinggi akan berdampak pada ketidakpuasan dan secara otomatis akan berdampak ketidak keloyalan. Semakin rendah harga maka akan semakin tinggi nilai kepuasan dan loyalitas, semakin tinggi harga maka akan berdampak terhadap ketidak kepuasan dan ketidak keloyalan.

4. Bedasarkan hasil analisis pengujian ditemukan bahwa variabel kepuasan konsumen dan loyalitas memiliki pengaruh yang signifikan atau memiliki pengaruh tertinggi dibadingkan kualitas produk dan harga, maka berdasarkan penelitian ini kedua variabel tersebut membuktikan bahwa kepuasan konsumen dan loyalitas memiliki hubungan atau keterkaitan yang erat satu sama lain. Jika dalam menjalankan bisnis online penjual memfokuskan dalam meningkatkan nilai kepuasan maka secara otomatis loyalitas konsumen akan tumbuh. Loyalitas merupakan nyawa dalam berwirausaha atau berbisnis, jika seorang itu loyal maka nilai pendapatan/ laba akan bertambah dan meningkat.

5. Bagi peneliti selanjutnya, disarankan untuk menggunakan kembali variabel kualitas produk serta meneliti objek toko online yang berbeda, kualitas produk merupakan variabel utama dalam 
menganalisis toko online guna untuk mengetahui tingkat kepuasan dan loyalitas karna sifat toko online yang berbeda dengan toko fisik atau offline. Penelitian selanjutnya diharapkan menambah variabel bebas sesuai dengan kebutuhan untuk meneliti toko online atau jika mendapati fenomena (variabel) baru untuk meneliti toko online.

\section{IMPLIKASI PENELITIAN}

Diharapkan hasil penelitian ini dapat menambah wawasan bagi pelaku usaha di bidang bisnis online, untuk memperhatikan kualitas dari produk, harga, untuk menumbuhkan loyalitas dan kepuasan konsumen.

\section{DAFTAR PUSTAKA}

Ali, F., Kim, W. G., Li, J., \& Jeon, H. M. (2018). Make it delightful: Customers' experience, satisfaction and loyalty in Malaysian theme parks. Journal of Destination Marketing \& Management, 7, 1-11.

Alma, Buchari, 2013, Manajemen Pemasaran Dan Pemasaran Jasa, Alfabeta, Bandung.

Cheng, B. L., Gan, C. C., Imrie, B. C., \& Mansori, S. (2018). Service recovery, customer satisfaction and customer loyalty: evidence from Malaysia's hotel industry. International Journal of Quality and Service Sciences. https://doi.org/10.1108/IJQSS-09-2017-0081

Delima, A., Ashary, H. M., \& Usman, O. (2019). Influence of Service Quality, Product Quality, Price, Brand Image, and Promotion to Consumer Satisfaction Affecting on Consumer Loyalty (Online Shop). Product Quality, Price, Brand Image, and Promotion to Consumer Satisfaction Affecting on Consumer Loyalty (Online Shop)(January 1, 2019).

Faith, D. O., \& M. Edwin, A. (2014). A Review of The Effect of Pricing Strategies on The Purchase of Consumer Goods. International Journal of Research in Management, Science \& Technology.

Fenalosa, Aldo (2018), Kilas Balik Ecommerce Platform di Indonesia Tahun 2018,https://iprice.co.id/trend/insights/kilas-balik-e-commerce-di-indonesia-tahun2018/, (diakses tanggal 4 april 2018 jam 22.20).

Gómez, M., Martín-Consuegra, D., Díaz, E., \& Molina, A. (2018). Determinants and outcomes of price premium and loyalty: A food case study. Journal of Consumer Behaviour, 17(1), 6474.

Hallencreutz, J., \& Parmler, J. (2019). Important drivers for customer satisfaction-from product focus to image and service quality. Total Quality Management \& Business Excellence, 1-10.

Hsu, C., \& Wang, D. (2011). Switching Costs and Influence on Customer Loyalty in the Online Shopping Market. (English). Marketing Review / Xing Xiao Ping Lun.

Hult, G. T. M., Sharma, P. N., Morgeson, F. V., \& Zhang, Y. (2018). Antecedents and Consequences of Customer Satisfaction: Do They Differ Across Online and Offline Purchases? Journal of Retailing. https://doi.org/10.1016/j.jretai.2018.10.003 
Jiang, K., Luk, S. T. K., \& Cardinali, S. (2018). The role of pre-consumption experience in perceived value of retailer brands: Consumers' experience from emerging markets. Journal of Business Research, 86, 374-385.

Kotler dan Keller. (2017). Manajemen Pemasaran, Edisi 12, Jilid 1, PT.Indeks,. Jakarta. In $e-$ Jurnal Riset Manajemen.

Lenzun, J. J., Massie, J. D., \& Adare, D. (2014). Pengaruh kualitas produk, harga dan promosi terhadap kepuasan pelanggan kartu prabayar telkomsel. Jurnal EMBA: Jurnal Riset Ekonomi, Manajemen, Bisnis dan Akuntansi, 2(3).

Li, D., Nagurney, A., \& Yu, M. (2018). Consumer learning of product quality with time delay: Insights from spatial price equilibrium models with differentiated products. Omega, 81, 150-168.

Li, W., Hardesty, D. M., \& Craig, A. W. (2018). The impact of dynamic bundling on price fairness perceptions. Journal of Retailing and Consumer Services, 40, 204-212.

Lupiyoadi Dan Hamdani, 2014, Manajemen Pemasaran Jasa, Salemba Empat, Jakarta.

Meesala, A., \& Paul, J. (2018). Service quality, consumer satisfaction and loyalty in hospitals: Thinking for the future. Journal of Retailing and Consumer Services, 40, 261-269.

Morisada, M., Miwa, Y., \& Dahana, W. D. (2019). Identifying valuable customer segments in online fashion markets: An implication for customer tier programs. Electronic Commerce Research and Applications. https://doi.org/10.1016/j.elerap.2018.100822

Noor $^{1}$, K. B. M., Rajiani, I., \& Sulaiman, N. A. M. The applicability of internal marketing factors to boost Internal service quality.

Supriyadi, Cecep (2017), Survei; Aktifitas Belanja Online Naik, Kepuasan Konsumen Turun, https://marketing.co.id/aktivitas-belanja-online-naik-kepuasan-konsumen-turun/, (diakses tanggal 5 april 2018 jam 10.20).

Tjiptono, Fandy, 2014, Pemasaran Jasa Prinsip Penerapan Dan Penelitian, Andi Offset, Yogyakarta.

Vasic, N., Kilibarda, M., \& Kaurin, T. (2018). The Influence of Online Shopping Determinants on Customer Satisfaction in the Serbian Market. Journal of Theoretical and Applied Electronic Commerce Research. https://doi.org/10.4067/s0718-18762019000200107

Xhema, J., Metin, H., \& Groumpos, P. (2018). Switching-Costs, Corporate Image and Product Quality effect on Customer Loyalty: Kosovo Retail Market. IFAC-PapersOnline, 51(30), 287292.

Yoon, Y., \& Uysal, M. (2005). An examination of the effects of motivation and satisfaction on destination loyalty: a structural model. Tourism management, 26(1), 45-56. 